\title{
"For a Healthy London": The Socialist Medical Association and the London County Council in the 1930s
}

\author{
JOHN STEWART*
}

London's hospitals are never far from the news, recently for often depressing reasons. The inter-war period, however, saw expansion and development in the capital's municipal hospital service. Between 1921 and 1937 expenditure on centralized health services such as hospitals rose by a factor of nearly twenty, so that by the latter date London accounted, Lee suggests, "for almost a quarter of national expenditure on centralised health care". This confirmed the capital's primacy "as the major national centre of hospital medicine". In so expanding, London was almost certainly advantaged in that the economic depressions of the period hit the city relatively lightly. This was in contrast to other areas, for example the Manchester region, where, as Pickstone points out, development of the hospital services was constrained by the collapse of the cotton industry and the general depression of the 1930s. ${ }^{1}$

London also had some of the most prestigious voluntary hospitals. These were independent institutions, reliant for their income on donations and subscriptions, and included such famous teaching hospitals as St Thomas's. There were significant differences between municipal and voluntary hospitals, however, not least in that the former bore the brunt of care for the long term and chronic sick. And as Esther Rickards, a Labour member of the London County Council (LCC), commented in 1938, municipal general hospitals provided over 22,000 beds for London's people. The voluntary hospitals, on the other hand, provided 15,000 "but only 9,000 of these are available for the inhabitants of London, the remainder being occupied by patients from outside the county". An official post-war LCC publication made a similar point, adding that this situation prevailed despite the presence of "twelve teaching hospitals and many other well-known voluntary hospitals". Sir George Newman, former Chief Medical Officer to the Ministry of Health, summed the situation up in 1939 by describing the LCC as the "greatest Local

*John Stewart, School of Humanities, Oxford Brookes University, Oxford OX3 OBP.

I am grateful to the Wellcome Trust for its support of my research on the history of the Socialist Medical Association; this journal's anonymous referees for their constructive comments on an earlier draft; and the archivists of the University of Hull, which holds the Socialist Medical Association archive (prefixed DSM), and that of Somerville Hastings (prefixed DSH), the British Medical Association, which holds the records of the Medical Planning Commission, and the Greater London Record Office, which holds the records of the London Labour Party (prefixed Acc2417) and the London County Council, including the Hospital and Medical Services Committee (prefixed LCC/MIN/22XX).

\footnotetext{
${ }^{1}$ Roger Lee, 'Uneven zenith: towards a geography of the high period of municipal medicine in England and Wales', J. hist. Geogr., 1988, 14 (3): 260-80, pp. 269 table 4, 268; John V Pickstone, Medicine and industrial society, Manchester University Press, 1985, p. 251.
} 


\section{John Stewart}

Health Authority in the Empire". ${ }^{2}$ In numerical terms this was certainly the case, the LCC being the largest single provider of hospital beds in Britain, and possibly the world.

Two important points arise here. First, the 1929 Local Government Act was crucial in London's hospital development. It allowed local authorities to take over Poor Law infirmaries and transform them into municipal hospitals, and the authority which took most advantage of this was the LCC. Poor Law institutions, as well the hospitals of the Metropolitan Asylums Board, were appropriated. The aim was, as Sheldrake puts it, to give hospital patients the right to admittance "simply as sick persons rather than as recipients of poor relief". Appropriation involved a massive shift in the nature and volume of London's public health provision, and the institutional care of the sick became the responsibility of the newly-created Central Public Health Committee. As Rivett remarks, this was a huge task taking several years to complete. ${ }^{3}$

Second, there was a political dimension. In 1929 the LCC was controlled by the Municipal Reform Party-effectively the Conservative Party-which was ideologically disinclined to spend money on increased services, especially given the general economic circumstances of the early 1930s. In 1934, however, the Labour Party won control of the LCC and thereby gained, as The Hospital noted, "in its Health Service an instrument of the greatest potency". 4 Labour's London victory was also important nationally, for the party had suffered a catastrophic defeat in the 1931 General Election, a position only slightly improved upon in 1935. Capturing the LCC, and retaining it with an increased majority in 1937, was therefore a considerable boost to Labour's morale. Much faith was invested in local government's power to provide the sort of social services which the National Government was unable or unwilling to countenance, despite mounting evidence of the problems of, for example, medical care. It is the Labour LCC's municipal health strategy, especially regarding hospitals and maternity services, which is examined in this article. Particular emphasis is placed on the activities of the Socialist Medical Association (SMA), founded in 1930 and affiliated to the Labour Party the following year. The SMA had a considerable impact on the development of Labour's health policy, although ultimately its plan for a socialized medical service was to be only partially realized. ${ }^{5}$

\footnotetext{
${ }^{2}$ Geoffrey Rivett, The development of the London hospital system 1823-1982, London, King Edward's Hospital Fund for London, 1986, p. 202; Esther Rickards in the London News, September 1938cutting in LCC General Hospitals Division Official Cuttings Book, Greater London Record Office; London County Council, The hospital servicefuture development: . . . report of the hospital and medical services committee, 11th December 1945, London, LCC, 1946, p. 3; quoted in John Sheldrake, 'The LCC hospital service', in Andrew Saint (ed.), Politics and the people of London: the London County Council 1889-1965, London, Hambledon Press, 1989, p. 195.

${ }^{3}$ Sheldrake, op. cit., note 2 above, pp. 187-92,
}

197; and Rivett, op. cit., note 2 above, p. 199ff. See also Gwylim Gibbon and Reginald Bell, History of the London County Council 1889-1939, London, Macmillan, 1939, ch. 13; and, for details of the hospitals taken over, London County Council, The LCC hospitals: a retrospect, London, LCC, 1949, Appendix II.

${ }^{4}$ The Hospital, Dec. 1935, p. 320.

5 On the SMA, and its treatment by historians, see John Stewart, 'Socialist proposals for health reform in inter-war Britain: the case of Somerville Hastings', Med. Hist., 1995, 39: 338-57; idem, 'The "Back-Room Boys of State Medicine": David Stark Murray and Bevan's National Health Service', $J$. med. Biog., 1996, 4: 229-35. 


\section{The SMA and London Politics}

The Association was always, in membership terms, heavily represented in London. At the 1945 General Election six of the twelve SMA members elected sat for constituencies in or around the capital. These included such important Association figures as its founding president, Somerville Hastings, recently chairman of the LCC Hospital and Medical Services Committee. Other Association MPs, although elected to constituencies outside the capital, none the less had experience of London politics. ${ }^{6}$ All this built on Association strength within the LCC, especially after 1934.

Hastings, a surgeon at the Middlesex Hospital, was an especially significant figure in London medical politics. The MP for Reading in the first two Labour governments, Hastings was elected LCC member for Mile End in 1932, a seat he retained until 1946, by which time he was back in the Commons, representing Barking. In 1934 Hastings became chairman of the LCC Hospital and Medical Services Committee-successor to the Central Public Health Committee, and on which he had served since 1929-holding this post until 1944, when he became Council chairman. Hastings was also, from 1934 to 1950, a member of the Executive Committee of the London Labour Party (LLP); a leading member, and for a long period chairman, of the Labour Party's Public Health Advisory Committee from just after the First World War until the 1940s; and a regular SMA delegate to Labour Party conferences. He was a vigorous advocate of the LCC as a model for health service reorganization, a view shared by a majority of the SMA. ${ }^{7}$ Hastings' significance should not, however, obscure the differences within the medical Left, and indeed within the SMA itself, over the administration and control of any future socialized health service. As will be shown, critics of the LCC model included such important Association figures as the London GP, and LCC member, Charles Brook. Such disagreements weakened the case which Hastings and his supporters put forward, and point to a fluidity of opinion on the Left over what form a socialized medical service should take.

None the less, the wider importance of Labour's control of London's hospital services was argued by a number of contemporary commentators. In 1949, shortly after the inauguration of the National Health Service (NHS), the socialist propagandist for science and SMA member Ritchie Calder suggested that the "LCC's Hospital Scheme Showed State the Way". The NHS rested "solidly on the work of the local authorities", and especially London's. ${ }^{8}$ It is to the activities of the capital's socialist medical politicians in the 1930s that we now therefore turn.

Even before the SMA's creation a number of its founder members were active in metropolitan political life. Hastings, Brook, Rickards, Stella Churchill and Santo Jeger, all soon to be prominent in the Association, were from 1929 members of the LCC Central Public Health Committee and its various sub-committees, either by appointment or as elected LCC representatives. They were therefore involved from the outset in the implementation of the 1929 Act in London. Alfred Salter, a Bermondsey general practitioner, was already famous as a campaigning doctor, and was a member of the LLP's

\footnotetext{
${ }^{6}$ Medicine Today and Tomorrow, 1945, 5 (3): $4-6$.

${ }^{7}$ On Hastings see Stewart, 'Socialist proposals', op. cit., note 5 above, passim; and the references in
}

Frank Honigsbaum, The division in British medicine, London, Kegan Paul, 1979.

${ }^{8}$ London News, Sept. 1949, p. 3. 
Executive Committee. ${ }^{9}$ An SMA London branch was formed in mid-December 1930 affiliating to the LLP in 1937-and around the same time Lewis Silkin, leader of the LCC Labour group, suggested that the Association prepare a health policy statement for the 1931 London elections. ${ }^{10}$ A first draft, Labour's hospital policy for London, was presented to the LLP Executive in January 1931. It had been written, a party official explained, by "a Committee of medical members of the Labour Party, including Dr A. Salter MP, Dr Somerville Hastings MP, and Dr C. W. Brook in consultation with Mr Lewis Silkin, leader of the Labour Party on the LCC Central Public Health Committee". Ultimately this document was produced as the election leaflet: For a healthy London: a municipal hospitals policy that will lessen suffering and disease.

For a healthy London noted the problems of the voluntary hospitals, caused in the main by "the ever-increasing complexity, and therefore costliness, of medical treatment". Municipal hospitals too would suffer if administered by a party, Municipal Reform, whose watchword was "keep down the rates". By contrast, a Labour administration would finally break the link between hospitals and the Poor Law. Patients would be admitted because they were London citizens needing treatment, for whom only "the best is good enough". The aim was not only to make London's municipal hospitals the best in the world, "but ultimately to make them free to all, rich and poor alike". Matters such as the problems of the voluntary system; the opportunities afforded by the 1929 Act; and the final aim of a free hospital service were fundamental to SMA thinking on medical reorganization.

Similarly, it was noted that Labour sought to develop London's municipal hospitals "as the Medical Centres of the districts in which they are situated", thereby encouraging "the home treatment of the sick poor being undertaken from these hospitals". What was being suggested was the creation of a system of health centres based on hospitals. Health centres-which were to be the medical focal point of each district wherein all health workers would work co-operatively-were central to the SMA's vision of a socialized medical service, not least because they would end the isolation of general practitioners from other medical workers. The leaflet concluded by arguing that for Labour the health of the nation was of "so great importance" that it was "unsafe to leave it to private charity". The moral was clear: "Vote Labour for an Efficient Public Hospital Service". In abbreviated form these proposals were incorporated in the 1931 Labour LCC manifesto. ${ }^{11}$

More generally, the faith in the 1929 Act's potential is also significant. In the late 1930s Hastings described its author, Neville Chamberlain, as the best ever Minister of Health, almost certainly as a consequence of his attempt to break up the Poor Law through the Local Government Act. Such a possibility was raised at the time by London's Labour

\footnotetext{
${ }^{9}$ Fenner Brockway, Bermondsey story: the life of Alfred Salter, London, George Allen and Unwin, 1949; LCC/MIN/2207, 28 Nov. 1929.

${ }^{10}$ David Stark Murray, Why a National Health Service?, London, Pemberton Books, 1971, pp. 24-5; DSM1/1, Report of the EC, 1930-31.

${ }_{11}$ Papers presented to the Executive Committee of the London Labour Party, Acc2417/A/15, folios 4397, 4400, 4479; London News, Feb. 1931, pp. 1 and 8 -Salter was one of the authors of this manifesto. Health centres were not, of course, the sole intellectual property of the Left, nor was there
}

agreement over how they should be organized and for what ends-some, for instance, saw them as enhancing the independence of the general practitioner: see, for example, Jane Lewis and Barbara Brookes, 'The Peckham health centre, "PEP", and the concept of general practice during the 1930s and 1940s', Med. Hist., 1983, 27: 151-61; and Charles Webster, 'The metamorphosis of Dawson of Penn', in Dorothy Porter and Roy Porter (eds), Doctors, politics and society: historical essays, Amsterdam, Rodopi, 1993. 


\section{The Socialist Medical Association and the LCC}

councillors who had suggested "building up through the transferred hospitals one of the most comprehensive municipal services in the world". ${ }^{12}$ At the time of Labour's victory in 1934, Hastings told an SMA meeting that, rightly used, the Act was "the key which would open the door to a complete and unified hospital system". It had come into being because "intelligent administrators were impressed by the wastefulness of two systems of treatment-one for poor-law patients and one for the public generally". If the legislation could be further used to end "the equally wasteful system of dual hospital administration"- that is public and voluntary - then it would be "of even greater value". In similar vein, in 1931 the Association's first Annual General Meeting, on a resolution from its London branch, had urged the amendment of the 1929 Act "so as to allow for free treatment at Municipal Hospitals". 13

For a healthy London, written by leading SMA activists, laid out the preoccupations of important members of the capital's medical Left in the early 1930s. The period between the Association's foundation and Labour's victory in 1934 saw considerable activity by its London members, again with Hastings taking a leading role. In the spring of 1933, for example, he addressed an LLP conference on the proposed cuts in London's public health provision. These supposed efficiency measures were, Hastings suggested, "an act of class war aimed at the standard of life of the working classes". Public health services should prioritize improving the community's health, not "the saving of pennies". ${ }^{14}$

The following month Hastings explained what a socialist administration would do for London's hospitals. He envisaged a "great municipal system", with local authority hospitals taking the lead and thereby encouraging the participation of the voluntary hospitals. Hastings and his SMA colleagues were anxious to see, eventually, the end of the voluntary system, which they viewed as both class divisive and symptomatic of the uncoordinated nature of existing health care provision. This lack of sympathy for voluntary hospitals was of some significance in London, where they were running into considerable financial problems by the late 1930s. The proposal to aid them with public money was not, however, looked upon favourably by Herbert Morrison-now leader of the LCC Labour group-and Hastings during meetings with Health Ministry officials in the late 1930s. Pater describes the relationship between London's municipal and voluntary sectors in the 1930s as one of "cold war", rather than the co-operation which in principle the 1929 Act encouraged. This bears out Prochaska's point that in the inter-war period the Local Government Act did "more to unsettle relations between the voluntary and public hospital sectors than any other piece of legislation". Hastings might be seen as contributing to this in what Abel-Smith describes as an "outspoken attack" on the voluntary hospitals. This included the suggestion that they would soon have outlived their usefulness, and that their absorption into a "National or Municipal system seems . . . certain within a comparatively few years' time". 15

\footnotetext{
12 DSM4/1, Circulars 1930-1939: Somerville Hastings, 'Some notes on the BMA scheme for a general medical service for the nation', pp. 3-4; Brian Barker, Labour in London: a study in municipal achievement, London, George Routledge and Sons, 1946, p. 64.

${ }^{13}$ Lancet, 1934, i: 1136; DSM1/1, Minutes of the First Annual General Meeting of the Association, 10 May 1931.
}

\begin{abstract}
14 London News, April 1933, p. 7.
15 London News, May 1933, p. 8; on Labour's attitude to London's voluntary hospitals see Charles Webster, The health services since the war, vol. 1, London, HMSO, 1988, pp. 3, 22, and idem, 'Labour and the origins of the National Health Service', in Nicolaas Rupke (ed.), Science, politics and the public good, London, Macmillan, 1988, p. 191; John Pater, The making of the National Health Service,
\end{abstract}




\section{John Stewart}

Hastings further argued in 1933 that "making our hospitals the medical centres of a district would be a useful step towards the development of a State Medical Service", again highlighting the SMA preoccupation with health centres and their role in the transition to a socialized health system. Finally, Hastings stressed the importance of hospital committees. While not going into any detail about the ideal method of constituting such bodies, he emphasized that Labour movement representatives had a particular responsibility to ensure the progress of both their hospitals and the health and welfare of London's citizens. ${ }^{16}$

\section{The 1934 LCC Election}

Further evidence of SMA influence can be found on the LLP's Health Research Group, one of a number of such bodies set up by Morrison. ${ }^{17}$ Chaired by Silkin, this had eleven members of whom five belonged to the Association. Its 1934 report, The public health of London, constituted a health manifesto for the impending elections. Noting the advances in public health, and their impact on the general death rate, the report none the less pointed to worrying trends in London health, including rising maternal mortality and deaths from diseases such as cancer. Ill-health was the product of three factors-poverty, bad sanitation, and inadequate medical care and treatment. The anarchy of capitalismreflected in uncoordinated health care provision-was therefore largely responsible for poor health and sickness. Municipal Reform's cost-cutting policies, particularly when directed at the social services, had caused "the general standard of health of the people of London" to decline. Labour, by contrast, stood for every person's right to "the best medical advice and treatment", saw health as "every bit as important as education"-an opinion often expressed by Hastings, and viewed the population's good health as "the greatest asset a nation can possess". There was therefore a need to attack the causes of illhealth by, for example, dealing with slum housing; improving the employment conditions of medical personnel and increasing their numbers; providing better facilities and treatment for patients; and continuing to break the link between health care and the Poor Law, particularly by exploiting the provisions of the 1929 Act to the full. The lack of coordination between various parts of the medical services was also critically noted. ${ }^{18}$

The public health of London, as befits a document produced at election time, was relatively imprecise, thereby reflecting the LLP manifesto, described by Donoughue and Jones as a "model of generalization". Not surprisingly, its priorities closely reflected the SMA's, and provided a platform from which Hastings and his Hospital Committee colleagues were to operate in the coming years. All this should also be put in the broader context of Morrison's strategy in 1934. One theme of his campaign, the most efficient

London, King Edward's Fund for London, 1981, p. 16; Frank Prochaska, Philanthropy and the hospitals of London, Oxford University Press, 1992, p. 111; Brian Abel-Smith, The hospitals, 1800-1948, London, Heinemann, 1964, pp. 365-6.

${ }^{16}$ London News, May 1933, p. 8.

${ }^{17}$ Bernard Donoughue and G W Jones, Herbert Morrison: portrait of a politician, London, Weidenfeld and Nicolson, 1973, p. 190.

\author{
${ }^{18}$ London Labour Party Health Research Group, \\ The public health of London, London, London \\ Labour Publications, 1934, pp. 3, 7, 9, 10-11, 12-13. \\ The SMA representatives were Salter, Hastings, \\ Esther Rickards, Amy Sayle and A J Gillison; on \\ Hastings' comments on the respective values of \\ education and health, see Stewart, 'Socialist \\ proposals', op. cit., note 5 above, p. 340.
}




\section{The Socialist Medical Association and the LCC}

Labour had carried out in London so far, was "A Healthy London", and this was backed up by a conference for LCC Labour candidates on health policy. ${ }^{19}$ The SMA played a vigorous part here, for example by contributing to the lectures on 'Planning and socialism' in 1933-34. Association members Hastings, Rickards, Jeger, G P Blizard and A J Gillison spoke on 'A healthy London: Labour's policy' and 'Poverty: a crime or a problem' ${ }^{20}$

Labour's victory in 1934 appeared to open up new opportunities for the capital's hospital services. As Morrison put it, "the Hospitals and Medical Services of the county will be improved and expanded, so as to give to our citizens a splendid civic service". ${ }^{21}$ It was therefore important that the election resulted in ten individuals closely associated with the SMA becoming LCC members, and in the following years they served on a range of Council bodies. Brook became chairman of the Welfare of the Blind Committee. Rickards, a surgeon who had allegedly been subject to employment discrimination in London hospitals because of her socialist beliefs, was to her surprise made chairman of the Establishments Committee. Hastings joined the important Public Assistance Committee and later the Air-Raid Precautions Committee, while others served on the Town Planning and Housing, Public Health, Public Control, and Parliamentary Committees. However the SMA's impact was most apparent on the Hospital and Medical Services Committee where its existing representation was further supplemented to the extent that it now contributed nearly one-third of the Committee's total membership of twenty-four. ${ }^{22}$

\section{The Hospital and Medical Services Committee}

At the Hospital Committee meeting of 21 March 1934, Hastings, on the nomination of Jeger and Brook, was elected unopposed as Committee chairman, a post he held for the next ten years. Association activists were also members of various sub-committees of the main body-for example Blizard, Brook, Jeger, Rickards and Hastings served on the Hospital Management Sub-Committee-and on hospital boards to which the Committee had the power of appointment. So, for instance, Caroline Maule and Stella Churchill were on the committees of, respectively, Archway and St Margaret's Hospitals. ${ }^{23}$

From 1934 the SMA was, therefore, in a position to influence the health services of the nation's and world's greatest single provider of medical care, a point explicitly made in the 1934 Executive Committee Report. The Association had, it claimed, the opportunity to "play a most important part in developing Labour's policy on public health and hospital services at the London County Hall" given the important positions its members held. ${ }^{24}$ This was significant, not least in terms of the development of Association ideology. David

\footnotetext{
${ }^{19}$ Donoughue and Jones, op. cit., note 17 above, p. 190.

${ }^{20}$ London Labour Party Conference Papers, Acc2417/G/2, 'The work of the London Labour Party, 1933-34', p. 9.

21 Acc2417/O/34, offprint of Herbert Morrison, 'New era for London', Labour, May 1934, p. 197.

22 DSM1/1, Annual General Meeting 1934, EC Report. Those concerned were full members Brook, Gillison, Hastings, Homa, McClements, and Rickards; and associate member Sayle. Two other associate members became Aldermen: William
}

\author{
Bennett and G P Blizard. The latter had served with \\ Hastings on the Labour Party's Advisory Committee \\ on Public Health; Donoughue and Jones, op. cit., \\ note 17 above, p. 193; Charles Brook, Making \\ medical history, London, Percy P Buxton, 1946, p. 2; \\ Minutes of the London County Council, 20 March \\ 1934 , and subsequently. \\ ${ }^{23}$ LCC/MIN/2211, 21 March and 26 April 1934; \\ Minutes of the London County Council, 19 Nov. \\ 1935; DSM1/1, AGM 1934, EC Report. \\ ${ }^{24}$ DSM1/1, AGM 1934, EC Report.
}


Stark Murray, a leading member, pointed out in May 1934 that Labour's victory made the SMA look at the question of socialized medicine "from an entirely new point of view". Previously some form of national health care system had been envisaged. But the capturing of the LCC, which had the machinery to meet the demand for medical services run by a local authority, significantly changed the picture. A socialized medical system might be reached by a route, the local, "we have not yet adequately explored". ${ }^{25}$ As shall be seen, not all on the medical Left were to agree. None the less, the LCC provided Association members with an opportunity to put into practice their developing ideas on health care provision.

Hastings' election as Hospital Committee chairman was central to SMA influence. He had, it was later claimed, the respect not only of his Labour colleagues, but also of the LCC medical staff, his Conservative medical opponents, and the council's new leader, Morrison. The last point was important, for three reasons. First, Morrison was perfectly capable of keeping out of office those whom he did not trust, for example SMA member Santo Jeger, although this did not prevent Jeger becoming vice-chairman of the Parliamentary Committee in 1935. Second, the paths of Morrison and the Association were from now on intertwined, most notably during the Labour Party debates over the organization of the post-war NHS when both argued, unsuccessfully, for local government control. And, third, Morrison was prepared to allow his committee chairmen considerable latitude once entrusted with their positions. ${ }^{26}$ This, therefore, offered Hastings and his colleagues scope to put their ideas into practice.

SMA influence on the Hospital Committee can also be usefully put in the broader context of developments within the Labour movement, for 1934 saw the passing at the Labour Party annual conference of a resolution seeking a national health service. Hastings, the Association delegate, was instrumental in having this adopted. ${ }^{27}$ Although more problematical than it at first appears, this does suggest that socialized medical care was becoming an important issue on the political Left, and that for medical activists like Hastings the LCC could provide a useful locus for reform and a platform for propaganda.

The Hospital Committee was certainly active in expanding the volume of financial resources available for health. During the period 1934 to 1940, hospital expenditure increased from $£ 3.9 \mathrm{~m}$ in $1933-34$ to a peak of $£ 5.3 \mathrm{~m}$ in $1938-39$, falling back slightly to $£ 4.6 \mathrm{~m}$ in $1939-40$. This constituted between 13 per cent (1939-40) and 17 per cent (1938-39) of total Council spending. Hospital expenditure increased more quickly than spending overall down to 1938 , falling behind slightly thereafter, although it remained easily the third largest item after education and public assistance. ${ }^{28}$ Hastings encapsulated Labour's sense of achievement over the increased allocation of resources to hospitals in June 1939. Proposing the 1939-40 financial estimates, he suggested that it was "with genuine satisfaction that I move these estimates. London has reason to be proud of its Municipal Hospital System". This pride was shared by Morrison, who complained to the BBC if a London municipal hospital was mentioned on the radio without the prefix "LCC", and who in 1936 described his Council as the "greatest hospital organisation in

\footnotetext{
25 Socialist Doctor, 1934, 2 (3): 1.

${ }^{26}$ Donoughue and Jones, op. cit., note 17 above, pp. 192-4; Minutes of the London County Council, 19-20 March 1935.

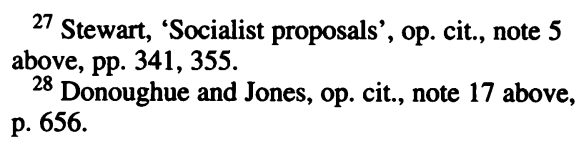




\section{The Socialist Medical Association and the LCC}

the world". ${ }^{29}$ Of course this investment was not an end in itself; it had particular aims and it is to what Labour in general, and the SMA's health professionals in particular, wanted out of improved medical services that we now turn.

As suggested, Labour activists tended to see health as a class problem, deriving from the inequalities of capitalism; the poor physical environment in which working people lived and worked; and the lack of resources for public services which should, by their very nature, be more widely available without punitive economic or social implications. In 1935 Labour's health strategy for London was outlined in London under socialist rule. This announced that since 1934 "decisions have been taken to enlarge, modernize, or otherwise improve, no less than 30 hospitals". The numbers of medical, nursing and ancillary personnel had all been increased, and employment conditions enhanced. Behind this lay Labour's determination that 'London's seventy-four municipal hospitals shall provide a service second to none, free from any Poor Law taint, which all classes of citizens will be proud to use". Of course caution had to be exercised-partly to avoid any disruption of services through too-rapid expansion, partly for "financial reasons". Since 1 July 1935, payment for services had been taken out of the hands of the Poor Law's successor, the Public Assistance Committees; none the less, charges still had to be made, although much less punitively than previously. Overall, however, the tone was optimistic and the message positive. ${ }^{30}$ Clearly it was felt that, even after only one year, Hastings and his colleagues had much to be proud of and to look forward to.

This analysis was shared and expanded upon by Brian Barker in his testament to the Labour LCC's successes published in the mid-1940s. Barker contrasted the "harsh and drastic policies of Public Assistance administration" before 1934 with the situation thereafter. New regulations were put into force abolishing "the deliberately penal aspects of relief'. The Labour Council early on adopted a policy of breaking up the mixed workhouses: consequently those requiring "constant medical attention were transferred to the hospitals, mental cases were brought under the care of special homes or the appropriate mental hospital, and all 'Poor Law' maternity cases were transferred to the more fitting care of the Hospitals and Medical Services Committee". Labour wanted hospitals removed from the Poor Law partly to take control away from the Ministry of Health; and partly because its hospital patients were technically "poor persons" and usually needed the consent of the relieving officer to gain admission, so making it impossible for public confidence to be created in a service "so obviously part of the notorious Poor Law system". Labour changed this, and Morrison was consequently able to tell the Council that the "only way a relieving officer could enter an LCC hospital was by becoming a patient". 31

The following years of Labour rule saw Hastings and his colleagues attempting to keep up the pace of health reform. The continuing dissociation of the health services from the Poor Law had already been addressed in February 1935. The Hospital Committee proposed the appropriation of four more institutions as the next step in pursuing the policy

${ }^{29}$ London News, June 1939, p. 3; Donoughue and Jones, op. cit., note 17 above, p. 200; quoted in the Daily Telegraph, 9 Nov. 1936 cutting in LCC General Hospitals Division Official Cuttings Book.

${ }^{30}$ Herbert Morrison and D H Daines, London under socialist rule, London, Labour Party, 1935, pp. 7-9; see also London Labour Party, Socialist planning in London, London, London Labour Party, 1935.

${ }^{31}$ Barker, op. cit., note 12 above, pp. 121, 127, 131-2, 138-9. 


\section{John Stewart}

of "taking all the hospitals under the Committee's management out of the scope of the Poor Law". ${ }^{32}$ Municipalization was central to the Committee's strategy, and Hastings spelled out some of its implications in April 1939. There were, he suggested, "many advantages" to having a number of hospitals controlled by one authority "as is the case with the LCC". Specialist care, for example, could be expanded and co-ordinated, with those suffering from particular problems being "segregated under the care of doctors and nurses with exceptional experience, greatly to their advantage". ${ }^{33}$ This was clearly not only a positive claim on behalf of the LCC hospitals, but an implicit attack on the voluntary sector. The latter were not part of any scheme of hospital care, hence what Hastings and his colleagues saw as the overlap, inefficiency, and lack of co-ordination in the existing system of health care.

As promised, staff conditions too were improved. In January 1937 Hastings reported that a new nurses' home, with accommodation for over 200 , had been opened at Lambeth Hospital at a cost of $£ 58,000$. The same year saw the reduction of nurses' hours at thirteen hospitals, and increases in medical and pathological staffs "with due regard to the interests of the patients". This was in line with the general improvement in LCC staff conditions under Labour. ${ }^{34}$ Supporters also argued that research flourished during Labour's rule. Barker claimed that "many important discoveries in medical treatment have been made by workers in the LCC hospitals", so putting paid to the "hoary calumny" that research would be stifled in a socialized medical service. On the contrary, London's "great Municipal Health Service ... provided the scope, the opportunity and the resources for medical research on a scale which enabled rapid progress to be made in many fields". Medical advances were partly due to the practice of grouping hospitals and the creation of specialist units serving part or all of the metropolis, for example the cancer treatment centre at Lambeth Hospital. Barker also highlighted the new pathological laboratories at Hampstead and Lambeth. ${ }^{35}$

In similar vein, the prominent obstetrician and SMA member Aleck Bourne told a BBC Home Service audience in 1943 that fears about a future health service being run inefficiently by civil servants were misplaced. Since London hospitals had been taken out of the hands of the Guardians they had "improved out of all recognition", the more advanced now competing in efficiency and progress with "any of the voluntary hospitals". In his famous "Penguin Special" of 1942, Health of the future, Bourne likewise stressed the LCC's research achievements and that London's hospitals were under the country's "most progressive management". ${ }^{36}$ Barker's and Bourne's emphasis on London's importance for the nation and its health services echoes Calder's point cited earlier.

Appropriation and improved staff conditions were all part of a broader expansion of hospital services. Hastings' comments on the significance of increased expenditure down to 1939 have already been noted. This was physically manifested by the building of a new maternity block at St Pancras at a cost of $£ 70,655 .{ }^{37}$ Barker was later to claim that within

32 LCC/MIN/2212, 28 Feb. 1935.

${ }^{33}$ London News, April 1939, p. 8.

${ }^{34}$ London News, Jan. 1937, p. 5; London Labour Party Conference Papers, Acc2417/G/3, 'The work of the London Labour Party, 1936-37', p. 35; Donoughue and Jones, op. cit., note 17 above, p. 196.

${ }^{35}$ Barker, op. cit., note 12 above, pp. 140-3.
36 DSM 5/1, unbound volume of press cuttings 1943-1945, Listener, 11 Feb. 1943; Aleck Bourne, Health of the future, Harmondsworth, Penguin, 1942, pp. 143-6.

${ }^{37}$ London Labour Party Conference Papers, Acc2417/G/3, 'The work of the London Labour Party, 1936-37', p. 35, and 'The work of the London Labour Party, 1937-38', p. 28. 


\section{The Socialist Medical Association and the LCC}

three years of Labour's LCC victory decisions had been taken to modernize, enlarge or reequip thirty-seven hospitals. Furthermore, outpatient services were provided at most general hospitals (unlike Poor Law practice), so these were increasingly able to "provide a comprehensive medical service to the surrounding community". This accords with Donoughue and Jones's observation that on coming to power in 1934 Labour quickly put together several three-year programmes for Council functions such as health. ${ }^{38}$

These points were made forcibly by Hastings in 1937. Reviewing the gains in hospital provision to date, he also recognized the problems which still lay before the achievement of his (and he stressed he was not talking of behalf of the LCC) vision of a comprehensive medical service. Hastings acknowledged that London suffered from "the division of responsibility and multiplicity of authorities". There were an "almost infinite number" of voluntary agencies providing services varying widely in quality and coverage. Similarly, Borough Councils and the LCC could find themselves, because of the capital's arbitrary division of health functions, duplicating services and administration. This was, however, much less of a problem in hospital bed provision. Now, in 1937, there were only six hospitals administered by the current version of the Poor Law, and as soon as places were found for those "needing institutional accommodation for reasons other than sickness", these too would be appropriated. The "Poor Law spirit", however, had not entirely disappeared, and Labour was determined that "every possible suggestion of charity, subservience, and general second-rateness" be abandoned. Instead, London's citizens should see "the municipal hospitals are their own"; each had "every right to use them and expect the best from them". The ultimate aim was to "equal or excel" the larger voluntary hospitals' high standards. This would take time, Hastings warned, admitting that there was a long way to go before London's municipal hospitals could be seen "as anything like perfect or complete". Indeed it was doubtful whether this was possible "within the limits of existing legislation". 39

This was a significant remark suggesting that even Hastings, local authority control's most fervent advocate, realized that substantial reforms would have to take place before the LCC model could be adopted elsewhere.

\section{Maternity Services}

However the Labour LCC was prepared to use existing or new legislation as positively as possible, as is witnessed by its activities in maternity care. Maternal mortality remained high in the 1930s. It was an issue vigorously promoted by, in particular, Labour women. LCC and SMA activist Esther Rickards argued that maternity provision should be a "public service-publicly financed". ${ }^{40}$ Shortly after the Labour LCC victory, the Hospital Committee reported that, as a result of considerable agitation on its part, the Council had agreed in November 1934 to the ambulance service being extended so that under normal

\footnotetext{
${ }^{38}$ Barker, op. cit., note 12 above, pp. 142-3; Donoughue and Jones, op. cit., note 17 above, p. 199.

39 Somerville Hastings, "The municipal hospitals of London: what they are and what they may be', Medicine Today and Tomorrow, Oct. 1937, no. 1: 3-6.

40 Esther Rickards, 'A national maternity scheme', Socialist Doctor, 1933, 2 (2): 4. For a discussion of
}

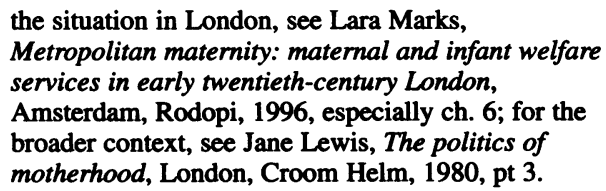




\section{John Stewart}

conditions all women could expect free provision as soon as they went into labour. ${ }^{41}$ This is a significant example of the Committee's attempt to introduce comprehensive services, free where possible, and without pauper stigma.

Further scope for development came with the 1936 Midwives Act which made local authorities responsible for the provision of a full-time, salaried midwifery service. The Hospital Committee, discussing the Bill in March 1936, regretted its omission of a number of issues. In particular, it did not allow for the limiting of medical aid to "approved medical practitioners who would be specially qualified". This concern coincided with the SMA position that maternity care should be provided by specialists, and thereby taken out of the hands of general practitioners. In turn, this was part of a wider contemporary debate about the efficacy of domiciliary care at childbirth. A deputation to the Health Ministry in January 1936 had been unsuccessful in progressing such matters. ${ }^{42}$ The Committee, however, did not let the issue lapse. The following June it informed the Ministry that negotiations were under way with the London branch of the British Medical Association (BMA) for "an approved list of practitioners to be available for the use of midwives" when they had to summon medical aid. The Committee also asked the Ministry what action should be taken to ensure expert help in domiciliary maternity cases given that the LCC had, apparently, no powers to employ an obstetric consultant. The concern here was that the Act did not allow for the creation by the LCC of a "flying squad" of specialist help for difficult confinements. ${ }^{43}$

These problems notwithstanding, Hastings reported, in August 1937, the LCC's determination to use the Act "to weld together the services provided by the Council, the Borough Councils, and the voluntary agencies". The domiciliary scheme was not the only option available to London mothers, as he pointed out. Labour's commitment to better maternal care was already showing results, not least in the increase in the number of confinements in LCC hospitals, in itself a partial consequence of the 1929 Act. $^{44}$ But it was the domiciliary service which attracted the most attention, and Hastings claimed later in 1937 that, after "months of hard work and repeated consultation with the many agencies concerned", the Council now had in place a suitable scheme which was to come into force on 1 January 1938, with Ministry of Health approval.

For women wishing to give birth at home, the LCC would have available nearly fifty full-time midwives. In addition, arrangements had been made with voluntary organizations so that, overall, London women would be able to call on the services of upwards of 200 midwives. Mothers would be charged $£ 2$ for a first confinement and thirty shillings thereafter, although mechanisms were available to have fees remitted or reduced. At this stage there was still no possibility of an LCC obstetric "flying squad" for emergencies. Under the Act, this was a Borough Council responsibility, which in turn stressed the need for co-operation between all parties concerned in maternity provision. Indeed, some local authorities had already suggested that such specialist help would, in principle, be better handled by the London-wide authority. 45 .

\footnotetext{
${ }^{41}$ LCC/MIN/2212, 14 March 1935.

42 LCC/MIN/2213, 26 March 1936; on Hastings' attitude to professional care and maternity services, see Stewart, 'Socialist Proposals', op. cit., note 5 above, pp. 346-7; on the wider issue of maternal care, see Irvine Loudon, 'Deaths in childbed from
}

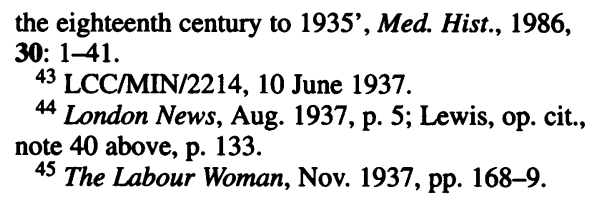




\section{The Socialist Medical Association and the LCC}

As Hastings acknowledged in 1937, there were still anomalies and overlap in the care London mothers might gain. Maternity and child welfare remained in Borough Council hands, while the domiciliary midwifery service was the responsibility of the LCC, which also provided "a large.number of hospital beds for maternity cases and young children". Hastings returned to this issue in late 1945-while the country awaited the NHS Billciting London's maternity provision as an example of the continuing lack of co-ordination of services. This was as absurd as "the presence of unconnected armies fighting one cause in a single area". ${ }^{46}$

However Hastings' tone and message in the 1930s were upbeat and optimistic, a position maintained by the LLP as a whole. Its 1938 annual report noted that the demand for Council midwives had been such that three more had been employed in July 1938, with the engagement of a further five authorized as soon as need dictated. In the first seven months of operation, LCC midwives had attended nearly 2,000 confinements, with a similar number of bookings arranged for the near future. ${ }^{47}$ All this led Hastings to claim, in 1940, that the LCC's provision for expectant mothers since 1934 showed "a better record [than] for any other class of people". The new municipal midwives service was growing in popularity; the number of beds in maternity wards had almost doubled between 1933 and 1939; and more babies-over 21,000 in 1938 compared to just under 12,000 in 1933-were being born in hospital. The result was a decline in maternal mortality at a rate of decrease faster than that of England and Wales as a whole. A post-war LCC publication made the same points, noting also the voluntary hospitals' deficiencies in maternity provision. ${ }^{48}$

This positive interpretation was shared by Barker, who maintained that under Labour "maternity services were, literally, transformed beyond recognition". He further stated that, before the war, "over 10,000 mothers every year were receiving midwifery and nursing attention" under the auspices of the Council's Home Midwifery and Maternity Nursing Service. Specific hospitals could also be singled out for praise. In 1936, for example, an LCC publication claimed that the low maternal mortality rate among East End mothers could be attributed to the care received at the East End Lying-In Hospital. ${ }^{49}$

The SMA strategy in London should also be viewed in the context of its critique of the maternity plan proposed jointly in 1938 by the BMA and the Trades Union Congress (TUC). To Hastings and his colleagues, this scheme was based on a number of erroneous assumptions, principally that every general practitioner who undertook maternity work did so willingly and with adequate knowledge; and that every woman had a GP conversant with her medical history. On the latter point, Hastings claimed that "as many as $95 \%$ of the mothers in one part of East London have no regular private doctor". Consequently, in addition to the dangers inherent in unwilling or ignorant doctors attending childbirth, there could be no continuity of ante- and post-natal care. ${ }^{50}$

\footnotetext{
46 Hastings, 'The municipal hospitals of London', op. cit., note 39 above p. 3; DSM 5/1 unbound volume of press cuttings 1943-1945, Municipal Journal, Oct. 1945.

${ }^{47}$ London Labour Party Conference Papers, Acc2417/G/3, "The work of the London Labour Party, 1937-38', p. 28.

48 London News, June 1940, p. 3; London County Council, The hospital service, op. cit., note 2 above, p. 6.
} 


\section{John Stewart}

It was just such problems that the London schemes sought to avoid, by attempting to sidestep general practitioners through the provision of specialist care in the form of midwives and, more problematically, obstetricians; by stressing the availability of both domiciliary and hospital services; and by trying to ensure adequate ante- and post-natal care. On the other hand the concerns acknowledged by Hastings undoubtedly suggested the need for a more comprehensive medical plan, further evidence of what he described as the problems of "existing legislation". Moreover the BMA/TUC alliance over maternity care was to have longer term implications for health care reform, as well as pointing to divisions on the Left over a future socialized medical system. As Honigsbaum has shown, the trade unions and the BMA were to continue their co-operation through the Beveridge Committee and into the founding of the NHS. One implication of this was that the unions were concerned to accommodate the BMA over certain issues, such as the latter's opposition to salaried GPs, as long as their own interests were met. Similarly, important unions were opposed, as was the BMA, to local authority control. Hence two of the key SMA demands for a socialized medical service were not supported by the TUC, its LCC successes notwithstanding. ${ }^{51}$ Clearly, therefore, obstacles created by important political and pressure groups stood in the way of the realization of a health service based on the London model.

\section{Conclusion}

With the coming of the Second World War, medical organization, in London as elsewhere, moved into a new phase, culminating in the creation of the NHS by the postwar Labour government. Clearly the Labour LCC's peacetime hospital and medical provision was, as the comments of Calder, Barker, and Bourne illustrate, viewed by some on the Left in an heroic light, an important achievement in itself as well as a precursor of the NHS. How accurate is this, and what historical significance do the activities and achievements of the LCC's Hospital Committee, led by SMA activists, have?

By the late 1930s the work of Hastings and his colleagues was influencing events beyond London itself. Webster notes that Health Ministry officials were reacting both to Labour policy initiatives "and to developments taking place in London, associated with the rise of the LCC hospital services and the decline of the voluntary sector" ${ }^{52}$ SMA evidence to the Sankey Commission on Voluntary Hospitals, set up by the British Hospitals Association in an attempt to find solutions to the problems confronting the voluntary sector, stressed the Association's ultimate aim of voluntary hospital absorption into a "complete, unified and co-ordinated Medical Service". However, short-term measures could be taken, for example over emergency hospital admissions. London and the larger provincial cities required a central co-ordinating office responsible for the speedy admission of emergency cases to the most appropriate hospital, municipal or voluntary. Association witnesses then described the situation in London whereby an "highly efficient and excellently organised" LCC department controlled ambulance services for street accidents and cases of infectious disease. This, they concluded, should be immediately extended to embrace "the admission of all emergency and urgent cases to

51 Honigsbaum, op. cit., note 7 above, ch. 24 . Health Service', op. cit., note 15 above pp. 190-1.

52 Webster, 'Labour and the origins of the National 
all General Hospitals in a specified area". In the capital such a task should be an LCC responsibility, since the Council already provided the public ambulance service. Here, then, was a very specific series of proposals put forward by SMA members, suggesting better use of existing facilities while not losing sight of the final aim of complete hospital integration. London's example was heavily drawn upon, unsurprisingly given that of the four Association witnesses to the Commission, three-Hastings, Brook, and Rickardswere LCC members. ${ }^{53}$

Furthermore, an important consequence of the London experience was the development by leading SMA members of a model for future health service provision wherein power was to be exercised by democratically controlled local authorities, centrally co-ordinated by the Ministry of Health. Democratic participation was extremely important to activists such as Hastings. As he told a meeting in 1942, even on health committees in a socialized service the final decision was to be made "by the consumer: that is by the elected representatives of the people". Drawing specifically on his LCC experience, he claimed that "there are many intelligent laymen and women who have a much greater insight into health questions than many doctors would give them credit for". This insistence on local democratic control was very much in line with a strong existing current in Labour thinking on social welfare provision, not least as held by key figures such as Morrison. ${ }^{54}$

Such an attitude was forcibly put, in 1941, by the Labour leader of the LCC, Charles Latham. Responding to an initiative which might have sidelined local government, Latham argued that "the fifth columnists against democracy are preparing to steal the people's municipal hospitals", part of a broader attack by "reaction" on popularly elected local government. Latham counterposed a comprehensive hospital system under local authority control. ${ }^{55}$ It was not surprising, therefore, that the LCC recommended to the Beveridge Committee that services such as hospitals should "be administered by local authorities". This was precisely the approach adopted in July 1942 at a special meeting of the Hospital Committee, whose SMA representation had been further strengthened by the co-option of David Stark Murray. Latham and Hastings also represented the LCC in discussions at the Health Ministry in early 1943. They again pushed the idea of local authority rights and control of health services, as did an SMA delegation consisting of Hastings, Bourne, Murray and Horace Joules. The Council took a comparable line on the 1944 White Paper. 56

Similarly, Hastings stressed the significance of local authorities in his capacity as a member of the BMA's influential Medical Planning Commission, arguing that they were not "necessarily inefficient, as many people appeared to think" ${ }^{57}$ It was clearly his own Council he had in mind. More generally, as a result of the size and apparent success of the LCC's interventions in health care, it was, as Webster points out, "strategically well placed

53 DSM (2) 5, General Correspondence 1930-1940, 'Submissions to the Voluntary Hospitals Commission' - the fourth witness was H B Morgan.

${ }^{54}$ Lancet, 1942, ii: 397 ; on the SMA's attitude to local control see Stewart, 'Socialist proposals', op. cit., note 5 above, pp. 347-9; and, idem, 'The "BackRoom Boys of State Medicine"', op. cit., note 5 above, pp. 232-3.

55 Quoted in Rivett, op. cit., note 2 above, p. 244.

\footnotetext{
56 Social Insurance and Allied Services: Report by Sir William Beveridge- Appendix G, Memoranda from Organisations, Parliamentary Papers 1942-43, vol. VI, p. 218; LCC/MIN/2219, 6 July 1942; Minutes of the London County Council, 30 June 1942; Pater, op. cit., note 15 above, pp. 56-7, 69; Rivett, op. cit., note 2 above, pp. 250-1.

57 Medical Planning Commission, Minutes of the General Practice Committee, 6 Aug. 1941, p. 4.
} 


\section{John Stewart}

to influence the Ministry of Health during the evolution of its thinking on a comprehensive health service". In parallel with this, the SMA had developed a close and apparently influential relationship with Ministry of Health civil servants. ${ }^{58}$ The importance of the LCC and its policies in the 1930s to the Labour Party, given the latter's problems at a national level, should likewise not be underestimated.

In the event, however, none of this was enough completely to convince Aneurin Bevan when he introduced his NHS plan. Negotiations with professional bodies and within the labour movement were complex, and the municipal, comprehensive, and unified plan put forward by bodies such as the SMA and the LCC was ultimately rejected in favour of a tripartite structure, part of which included hospital nationalization and concessions to the teaching hospitals. Furthermore it was Morrison, "a defender of local government in general and the London County Council in particular", who lost in the Cabinet struggle with Bevan. ${ }^{59}$ Bevan's plan can be seen as an important defeat for one possible option in the creation of a new health service, and one which has implications down to the present day. It was tantamount to the rejection of a particular vision of local democracy and local accountability in health care provision. This was ironic, given that, until 1945, the assumption in London Left-wing political and medical circles was that hospital services would be based on local authorities. As Latham put it in 1946, it was only reluctantly that the LCC would give up its hospital service, now the finest in the world, to the central state. Reluctantly or otherwise, however, the LCC was to swing behind the Bevan scheme. ${ }^{60}$

Moreover not all SMA members were as enthusiastic for municipal administration as Hastings. Charles Brook was, like Hastings, a member of the LCC and of the Medical Planning Commission. As Honigsbaum points out, Brook had also been involved with the Medical Practitioners' Union, an experience which convinced him of GP hostility to local authority control. In his 1946 account of the SMA's origins and early history, Brook reproduced a number of articles making this very point. In 1940, for example, he had drawn attention to both his LCC experience and the apparent unanimity of current proposals that "local authorities should be the supervising bodies". Brook argued, however, that it would be a "grave mistake" for local authorities to be given "any direct control of the domiciliary service". Furthermore, they should also "be deprived of their present functions of control of hospitals and medical services". The need for a "national service" was illustrated by the success of the National Insurance system, whose uniformity contrasted sharply with the "enormous disparity in the standards of efficiency of the local government health services" where in some cases "local autonomy has literally run riot". 61

Brook further elaborated on such points in his submissions to the Medical Planning Commission. He had no doubt that measures of democratic control were required and that there should be a "considerable degree of local autonomy". None the less, the proposed service must be "a national one and not placed under the local authorities". This would

\footnotetext{
58 Webster, The health services since the war, op. cit., note 15 above, pp. 78, 79.

59 Ibid., ch. 4, and idem, 'Labour and the origins of the National Health Service', op. cit., note 15 above, p. 197ff; Rivett, op. cit., note 2 above, p. 264; Pater op. cit., note 15 above ch. 5 .
}

\footnotetext{
${ }^{60}$ Rivett, op. cit., note 2 above, pp. 264, 265; Webster, The health services since the war, op. cit., note 15 above, p. 89.

${ }^{61}$ Honigsbaum, op. cit., note 7 above, pp. 182-3, 258; Brook, op. cit., note 22 above, pp. 21-2.
} 
ensure, inter alia, that "an optimum standardisation would be achieved". Clearly, Brook was not as enamoured of his LCC experience as Hastings was of his, and indeed by the early 1940s was evidently unhappy with his membership of the Council, from which he eventually resigned in $1942 .{ }^{62}$

Others too were sceptical about over-emphasis on local authority control. In 1944 Association member Stephen Taylor, from 1945 MP for Barnet, declared himself indifferent as to whether doctors were employed by "a Corporation, a medical board, local authorities, hospitals, or universities" provided certain safeguards were built in. Five years earlier, Taylor had been less reticent. In a wide-ranging article in the Lancet, one of his initial propositions was that London's specialist services were unsatisfactory, a radically different view from Barker's. Taylor further argued that positive aspects of the Emergency Medical Service such as regionalization and decentralization should be retained. However some national organization was necessary, but this should not be "part of the Ministry of Health, nor should it be connected with the local authorities". Rather, a National Hospital Corporation should be created, to be reviewed by parliament on a five-yearly basis. Among the benefits of such an organization would be an end to the situation whereby rich local authorities could develop "a fine municipal hospital service" while poor areas frequently had to make do with "converted public-assistance institutions". The scepticism of Brook and Taylor about municipal administration, and thereby the quality of care, was shared by others on the Left, for example the Fabian Society's Medical Service Group. ${ }^{63}$

In large part, the problem revolved around what was meant by "local authority". Even such vigorous advocates of the LCC as Hastings acknowledged that the London model was not necessarily transferable elsewhere, at least without extensive local government reorganization. Consequently, Hastings told the Medical Planning Commission that he "believed in regionalisation". The country should be divided into areas, possibly based on the twelve Emergency Medical Service areas, with an elected body administering all medical services. In the meantime, medical services should be administered by regional bodies with local authority representatives. Hastings repeated this argument in a Fabian pamphlet on the hospital services published in 1941. Similarly Bourne, while a propagandist of the LCC's achievements, was also prepared to advocate "regionalisation" by 1942.64

This raises two important points. First, the experience of wartime organization suggested to individuals such as Hastings a modified version of their local authority model, based on the obvious efficiencies of larger scale organization. Second, and leading on from this, the acknowledgement of the need for local government reorganization led Hastings to accept, at least in the short term, Bevan's proposed NHS structure. As he put

\footnotetext{
62 Medical Planning Commission, Session I, Appendix XV, Charles Brook, 'Problems of the postwar practitioner', p. 11; Minutes of the General Practice Committee, 2 July 1941, Charles Brook, 'The co-ordination of a national medical service', p. 8. On Brook's relationship with the LCC, see the correspondence in Acc2417/A/3.

${ }^{63}$ Stephen Taylor, Battle for health: a primer of social medicine, London, Nicholson and Watson, 1944, pp. 121-2; idem, 'A plan for British hospitals',
}

\begin{abstract}
Lancet, 1939, ii: 945-51 (I am grateful to one of this article's anonymous referees for the second of these references); Frank Honigsbaum, Health, happiness and security: the creation of the National Health Service, London, Routledge, 1989, p. 173.

64 Medical Planning Commission, Minutes of the General Practitioner Committee, 6 Aug. 1941, p. 3; Somerville Hastings, The hospital services, London, Victor Gollancz/The Fabian Society, 1941; Bourne, op. cit., note 36 above, pp. 146-8.
\end{abstract}




\section{John Stewart}

it in 1946, although local authority control might be a "desirable thing" in London, this was not necessarily the case throughout the country as a whole. Hence the logic of Bevan's NHS Bill. 65

However, Hastings did not give up his hopes of local government reorganization and, consequently, the kind of democratic control of the health services he had previously argued for. In 1947, for example, he told the SMA's Annual General Meeting that the 1946 Act was a "framework, sound in most (but not all) of its provisions". At the same meeting, a resolution was passed anticipating "the day when, following the inevitable reform of local government, the country's hospitals would be administered by local-government bodies". That this did not happen was to contribute to the later disillusionment of Hastings and others with Bevan and his scheme. ${ }^{66}$

Questions also have to be asked about the actual extent of change under the peacetime LCC Labour administration. Sheldrake suggests that the Council's achievements were "more in the realm of reorganization, rationalization and administration than in a massive programme of new hospital building". As he points out, the number of beds available had actually declined by 1939 , albeit as a result of increased efficiency of provision. ${ }^{67}$ Moreover, not all services which might be broadly defined as "medical" necessarily improved after 1934. In the field of mental health, for example, Thomson finds no dramatic change in policy after Labour's coming to power, although this should be put in the context of steadily rising expenditure. Increased expenditure also characterized the Welfare of the Blind Committee, led by Brook. ${ }^{68}$

There were also political and structural barriers to a full realization of the medical plans of organizations such as the SMA. The Labour LCC had to be sensitive to the feelings of Labour-controlled Borough Councils, which still had significant health functions. This division of health functions between London and Borough Councils was a cause of frustration to anyone seeking a co-ordinated system of medical care throughout the capital, as has been seen in the case of maternity provision. In turn, this raises the issue of how good the care provided by the LCC actually was. Supporters of the Labour administration such as Barker stressed the positive achievements of Hastings' Hospital Committee. Similarly, the LCC's "official" historians, Gibbon and Bell, emphasized the achievements of the 1930s, for example the increased space allowed to individual hospital beds. They also used photographs to demonstrate the "before and after" effect of hospital redecorating and refurbishment. ${ }^{69}$

However, this has to be qualified by the scepticism about London medical services of Left-wing medical personnel such as Brook and Taylor. Equally damning in this respect was the attitude of London's Medical Officer of Health, W Allen Daley, who in 1941 told a colleague in the Ministry of Health that many local authorities were too small to administer hospital services, and that even in London he personally was prepared to sacrifice local control. The view that hospitals should be nationalized was also

\footnotetext{
${ }^{65}$ Quoted in the Islington Gazette, 16 April 1946, cutting in the LCC General Hospitals Division Official Cuttings Book.

${ }^{66}$ Lancet, 1947, i: 689-90.

67 Sheldrake, op. cit., note 2 above, p. 188.

68 Matthew Thomson, 'Social policy and the management of the problem of mental deficiency in
}

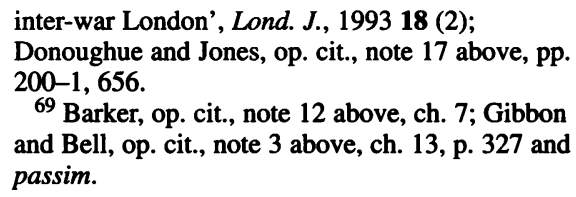




\section{The Socialist Medical Association and the LCC}

increasingly held in the Ministry itself by prominent officials who were thereby able to provide Bevan with additional ammunition for his own case. ${ }^{70}$ This was obviously in marked contrast to leading LCC figures, including Hastings. But even he was, as noted, concerned about the possibilities for further improvement under the legislation in place in the 1930s, and at least in part welcomed wartime innovations as conducive to better medical organization and thereby quality of care.

Furthermore, Morrison, while ambitious in his plans for London, was hardly fiscally reckless. As his biographers put it, "More than most socialists Morrison displayed a sense of proportion about public spending". He could not, therefore, "proceed as fast as he or enthusiasts for particular services desired". Morrison was also keen to prioritize housing. This had, of course, an important health function and the medical Left, including the SMA, always emphasized that combatting ill-health was not confined to the surgery or the hospital ward. None the less, decisions still had to be made about resource allocation, and clearly medical services were not always accorded top priority. Moreover, as the 1930s drew to a close another competing call on municipal funds emerged in the need to prepare for the protection of the civilian population in the event of war. ${ }^{71}$ In such circumstances, therefore, it is not surprising that even "enthusiasts for particular services" such as Hastings recognized the need for cautious progress and value for money.

In addition, the very scale and nature of what the LCC sought to achieve in the health field was frustrated by events beyond its control. As a post-war retrospective on the London hospital system noted, many institutions taken over after 1929 were not in the best condition, and the only solution was "a long-term plan, spread over many years". This was duly adopted, but the "carrying out of these schemes of construction and reconditioning was of course disastrously interrupted by the war". Another official post-war publication claimed that "[g]reat advances" had been made in the standard of treatment since 1930 but that, once again, "progress was arrested by the war". Hastings himself recalled that on the day war was declared he was about to sign a contract for the building of "what I still think would have been the best Special Hospital that the world has ever known. But of course all this had to be scrapped. I shall never forget my grief." 72 In consequence, the LCC achievement in the 1930s was based on the refurbishment of existing buildings rather than on any massive programme of new hospital construction. Finally, as Sheldrake correctly argues, many hospitals were badly sited; certain special hospitals lay outside the administrative area of the LCC; and the voluntary hospitals, which in any case were not under Council control, were largely concentrated in the capital's centre. ${ }^{73}$ Such factors clearly made the achievement of a fully integrated system difficult, if not impossible. Hence, perhaps, Hastings' scepticism about the extent to which existing legislation could ultimately satisfy his and his supporters' aspirations.

What, then, should be our final assessment of the socialist programme for health in London in the 1930s? Labour's 1934 LCC victory saw considerable power over the capital's peacetime health policy fall into the hands of the SMA, an organization committed to a socialized health service. It is no exaggeration to say that Association

\footnotetext{
${ }^{70}$ Daniel M Fox, Health policies, health politics, Princeton University Press, 1986, pp. 97-8; Pater, op. cit., note 15 above, pp. 178-9; and the comments in Sir George Godber, The health service: past, present and future, London, Athlone Press, 1975, pp. 18-19.

71 Donoughue and Jones, op. cit., note 17 above,
}

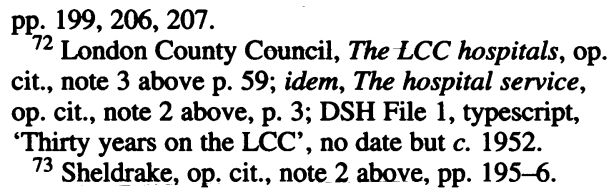

${ }^{73}$ Sheldrake, op. cit., note 2 above, pp. 195-6. 


\section{John Stewart}

members were instrumental in directing the capital's health policy after 1934, particularly through the Hospital and Medical Services Committee which had strong SMA representation, not least in the person of its chairman, Somerville Hastings.

The Committee had dynamic plans for the future of London's hospital service. These involved not simply further building and renovation, important as these were, but also the appropriation of remaining Poor Law institutions; the improvement of employment conditions for all staff, medical and ancillary; and, ultimately, the integration of all hospitals into a unified, free service. The ambitions and achievements of the hospitals system under the Labour administration in the 1930s clearly inspired sections of the Left, as is witnessed by the claims of Calder, Barker and Bourne. However there were a number of constraints to expansion in the 1930s, some of which were beyond the control of even such a powerful local authority as the LCC: hence the fulfilment of some projects, but also the frustration of part or all of others. This must make us qualify the achievements of Hastings and his colleagues. Even what was perhaps the most successful scheme introduced under Labour, that enhancing maternity provision, was not as unified and comprehensive as might have been desired. This is not, of course, to belittle its contribution to the decline in maternal mortality, simply to suggest that at an organizational level what was desired was not always achieved.

Similarly, the model provided by the LCC and developed by the SMA, of health services democratically controlled by local authorities, was not adopted by the post-war NHS. This was unexpected, in that local control had always appeared to be the road which would be taken. However, Aneurin Bevan declined to follow it. This resulted from his own predispositions, and those of influential officials; the pressures on him from organizations such as the BMA, longstanding opponents of local authority control; and the diversity of views on the medical Left, whereby the pro-local authority line of Hastings and the majority of the SMA was, none the less, challenged both outside and inside the Association. The "alliance" between the BMA and the TUC over certain medical matters is significant here, as are the criticisms of local authority control by Brook and Taylor. When combined with the failure to build health centres-especially in the potentially fruitful area in this respect of London-the structure of Bevan's NHS was later to lead to a certain disillusionment among SMA activists over what was actually achieved in the late 1940s.

Overall, therefore, the picture is one of qualified success which might, under different circumstances, have had a significantly different outcome. In an era when the various forms of health care provision were so complex, competitive, and overlapping as to hardly constitute a "system" at all, even the most vigorous organization would have found it difficult to do much more than the Labour LCC. Credit should therefore be given to the Labour administration, and particularly to the SMA, for achieving as much as they did. It would take the onset of a world war, and the accompanying centralization of control and questioning of all previous ideas, to move Britain towards a National Health Service. In so doing, the systems and achievements of London, if not ignored, were in themselves subjected to scrutiny and found to be, as far as Bevan and certain others on the Left were concerned, inappropriate to, or unachievable in, the political circumstances of the postwar world. However, now that the very future of the NHS is up for discussion, and the flaws in Bevan's scheme are increasingly evident, then perhaps the time is ripe for a reassessment of at least part of what Hastings and the SMA, not least by way of their activities on the LCC Hospital Committee, sought to achieve. 